\title{
Hubungan Siklus Menstruasi, Kualitas Tidur, dan Status Gizi, Terhadap Dismenore Primer pada Remaja Putri
}

\author{
Yani Amaliah Hikma, Moch. Yunus*, Anindya Hapsari \\ Universitas Negeri Malang, Jl. Semarang No. 5 Malang, Jawa Timur, Indonesia \\ *Penulis korespondensi, Surel: moch.yunus.fik@um.ac.id
}

Paper received: 23-7-2021; revised: 13-8-2021; accepted: 20-8-2021

\begin{abstract}
Dysmenorrhea is a form of pain that occurs during menstruation and manifests as abdominal pain. 90 percent of the 1,769,425 women in the study had dysmenorrhea, with 10-15 percent of whom had serious dysmenorrhea. Endocrine conditions, organic, constitutional, allergies, age at first menstruation 12 years, long menstrual cycle (greater than 7 days), heavy menstrual bleeding, and so on are risk factors for primary dysmenorrhea. The aim of this study at the Sabilurrosyad Gasek Islamic Boarding School in Malang was to see how the menstrual cycle, sleep quality, and nutritional status affect primary dysmenorrhea in adolescent girls. The research tool used in this analysis is correlational research with a cross sectional design approach. Purposive sampling was us ed to select 75 young women. To collect research data, a questionnaire/questionnaire was distributed. Spearman's rho test was used as bivariate analysis, and logistic regression test was used as multivariate analysis. The results showed that the menstrual cycle and primary dysmenorrhea in adolescent girls had a significant relationship $(0.0000 .05)$ with a strong relationship (0.771). Furthermore, there was a significant relationship between sleep quality and primary dysmenorrhea in adolescent girls $(0.0340 .05)$ ( 0.246 is weak), but there is no relationship between nutritional status and primary dysmenorrhea in adolescent girls (0.364 greater than 0.05$),(0.106$ is very weak). However, there was no significant relationship between the three independent variables in the multivariate analysis, with an EXP (B) value of 0.012 menstrual cycles.
\end{abstract}

Keywords: primary dysmenorrhea; menstrual cycle; sleep quality; nutritional status

\begin{abstract}
Abstrak
Dismenore merupakan nyeri yang terjadi pada waktu menstruasi memiliki tanda seperti rasa sakit di abdomen perut. Kejadian dismenore di alami oleh 90 persen dari 1.769.425 wanita, dimana 10-15 persen wanita mengalami dismenore berat. Terdapat beberapa faktor risiko yang dapat menyebabkan dismenore primer yaitu kelainan endokrin, organik, konstitusi, alergi, usia saat menstruasi pertama kurang dari 12 tahun, periode lama menstruasi (lebih dari 7 hari), perdarahan menstruasi yang berlebihan, merokok, dan lain sebagainya. Penelitian ini bertujuan untuk mengetahui hubungan antara siklus menstruasi, kualitas tidur, dan status gizi terhadap dismenore primer pada remaja putri di Pondok Pesantren Sabilurrosyad Gasek Malang. Penelitian korelasional dengan pendekatan desain cross sectional merupakan metode penelitian yang dipilih dalam penelitian ini. Subjek pada penelitian ini merupakan remaja putri sebanyak 75 responden dengan menggunakan teknik purposive sampling. Penyebaran angket/kuesioner dilakukan untuk memperoleh data penelitian. Analisis bivariat menggunakan uji Spearman'x rho dan uji regresi logistik yang digunakan sebagai analisis multivariat. Hasil dari analisis tersebut membuktikan bahwa terdapat hubungan yang signifikan antara siklus menstruasi terhadap dismenore primer pada remaja putri $(0,000$ kurang dari 0,05$)$ dengan kekuatan korelasi kuat $(0,771)$. Selanjutnya terdapat hubungan yang signifikan antara kualitas tidur terhadap dismenore primer pada remaja putri $(0,034$ kurang dari 0,05$)(0,246$ yang berarti lemah), dan tidak terdapat hubungan yang signifikan antara status gizi terhadap dismenore primer pada remaja putri $(0,364$ lebih dari 0,05$)(0,106$ yang berarti sangat lemah). Untuk analisis multivariat tidak ada hubungan signifikan yang bersamaan dari ketiga variabel bebas, akan tetapi nilai EXP(B) siklus menstruasi yakni 0,012.
\end{abstract}

Kata kunci: dismenore primer; siklus menstruasi; kualitas tidur; status gizi 


\section{Pendahuluan}

Masa remaja dikenal sebagai tahap kehidupan dimana seseorang mencapai proses kematangan emosional, psikososial, dan seksual. Salah satu tanda dimulainya masa remaja adalah mulai berfungsinya organ reproduksi, yang salah satu tandanya bagi remaja putri adalah menstruasi dan pada laki-laki adalah mimpi basah (Yusuf, 2012). Menstruasi merupakan terjadinya pelepasan lapisan endometrium uterus secara bertahap yang mengakibatkan perdarahan vagina (Janiwarty \& Pieter, 2013). Menstruasi tidak selalu berjalan lancar, banyak pula gangguan menstruasi yang bisa dihadapi wanita. Gangguan menstruasi biasanya menyebabkan ketidaknyamanan fisik bagi wanita yang dapat mengganggu aktivitas mereka (Saguni, et. al., 2013). Salah satu gangguan menstruasi pada wanita disebut dismenore (Dawood, 2010). Dismenore merupakan nyeri yang terjadi pada waktu menstruasi memiliki tanda seperti rasa sakit di abdomen perut (Hendarto, 2011).

Kejadian dismenore dialami oleh $90 \%$ dari 1.769 .425 wanita, dimana 10-15\% wanita mengalami dismenore berat (WHO (2012) dalam jurnal Delistianti, et. al (2019). Wanita muda usia 17-24 tahun dengan prevalensi 67-90\% lebih banyak mengalami dismenore. Sedangkan, prevalensi di Indonesia sekitar 54,89\% pada remaja wanita usia 14-19 tahun yang mengalami kejadian dismenore primer. Dimana dilaporkan rata-rata $>50 \%$ wanita mengalami dismenore primer di berbagai negara (Delistianti, et. al., 2019).

Terdapat beberapa faktor risiko yang dapat menyebabkan dismenore primer yaitu kelainan endokrin, organik, konstitusi, alergi, usia saat menstruasi pertama $<12$ tahun, periode lama menstruasi ( $>7$ hari), perdarahan menstruasi yang berlebihan, merokok, riwayat keluarga, kegemukan dan mengkonsumsi alkohol (Isnaeni, 2010).

Ada beberapa faktor yang menyebabkan dismenore primer dapat terjadi salah satunya adalah siklus menstruasi yang tidak teratur setiap bulannya, dimana kemungkinan tingkat nyeri yang dirasakan pada siklus menstruasi tidak teratur makin besar (Juliana, et. al., 2019). Siklus menstruasi dialami oleh remaja wanita pada hari pertama sampai datangnya periode selanjutnya (Sinaga, et. al., 2017). Sebesar 90\% wanita mengalami siklus menstruasi antara 2135 hari dan hanya $10-15 \%$ yang memiliki siklus normal sekitar 28 hari. Remaja wanita yang memiliki siklus tidak teratur dapat menyebabkan terjadinya masalah kesuburan (Saryono \& Sejati, 2009).

Selain siklus menstruasi, berdasarkan penelitian Bataha, et. al (2014), remaja putri yang kualitas tidurnya buruk dapat mengalami dismenore primer. Memperbaiki kualitas tidur dapat berdampak pada kesegaran dan kebugaran jasmani setiap individu (Khasanah, 2012). Hasil penelitian Delistianti, et. al (2019) terhadap mahasiswi Fakultas Kedokteran Universitas Islam Bandung menunjukkan bahwa sebesar 62\% (66 dari 106 mahasiswi) mengalami kualitas tidur buruk, sedangkan sebesar 38\% (40 dari 106 mahasiswi) mengalami kualitas tidur baik, sehingga dapat dikatakan bahwa sebagian besar mahasiswi mengalami kualitas tidur buruk.

Selain faktor siklus menstruasi dan kualitas tidur, ada faktor lain yang dapat mempengaruhi fungsi organ tubuh yaitu status gizi. Faktor dari status gizi bisa dijumpai dalam "fungsi reproduksi" (Waryana, 2010). Menurut Almatsier (2010), disimpulkan bahwa mengkonsumsi makanan dapat mempengaruhi status gizi, dimana zat-zat gizi berasal dari zat tertentu. Masalah gizi pada remaja biasanya sering terjadi pada gizi kurang, gizi lebih, dan obesitas (Adriani \& Wirjatmadi, 2012). Terganggunya fungsi reproduksi dikarenakan remaja mengalami status gizi kurang yang berdampak pada pertumbuhan dan fungsi organ tubuh. 
Akan tetapi, dampak tersebut bisa membaik dengan cara memberi asupan nutrisi yang baik untuk dikonsumsi oleh tubuh (Sibagariang, et. al., 2010). Selain pada remaja dengan status gizi kurang, dismenore primer dapat terjadi pada remaja dengan status gizi obesitas (overweight) karena banyak jaringan lemak di dalam tubuh sehingga dapat menekan pembuluh darah (Tristiana, 2017).

Peneliti melakukan studi awal di Pondok Pesantren Sabilurrosyad Gasek Malang dari 30 remaja wanita, sejumlah 22 remaja wanita pernah mengalami dismenore dan 8 remaja wanita tidak pernah mengalami dismenore. Dari uraian di atas, judul yang akan diteliti oleh peneliti yaitu hubungan siklus menstruasi, kualitas tidur dan status gizi terhadap dismenore primer pada remaja di Pondok Pesantren Sabilurrosyad Gasek Malang yang kemungkinan dapat mengganggu aktivitas sehari-hari.

\section{Metode}

Penelitian korelasional dengan pendekatan desain cross sectional merupakan metode penelitian yang digunakan dalam penelitian ini. Penelitian ini menggunakan dua variabel yaitu variabel bebas (siklus menstruasi, kualitas tidur, dan status gizi), dan variabel terikat (dismenore primer). Teknik purposive sampling yaitu teknik yang digunakan dalam mengambil seluruh anak putri Pondok Pesantren sebanyak 230 remaja putri mulai dari SMP, SMA dan Kuliah di Pondok Pesantren Sabilurrosyad Gasek Malang yang merupakan populasi penelitian. Sampel yang dibutuhkan dalam penelitian ini sebanyak 75 responden. Penelitian ini diambil dari penelitian terdahulu dan dimodifikasi, serta dilakukan uji etik penelitian. Pengambilan data dilakukan dengan menyebar angket kepada 75 responden. Analisis univariat, analisis bivariat (uji Spearman'x rho), dan analisis multivariat (uji regresi logistik) yaitu teknik analisis data yang digunakan penelitian ini.

\section{Hasil dan Pembahasan}

\subsection{Hasil}

\subsubsection{Karakteristik Responden Menurut Umur}

Tanggal 29-30 November 2020 dilakukan pengumpulan data dua variabel. Remaja wanita usia 15-25 tahun merupakan responden dari penelitian ini digambarkan sebagai berikut:

Tabel 1. Distribusi Frekuesi Karakteristik Umur Responden

\begin{tabular}{ccc}
\hline Umur Responden & Frekuensi & Persentase \\
\hline $15-18$ tahun & 35 & $46.7 \%$ \\
$19-22$ tahun & 29 & $38.7 \%$ \\
$23-25$ tahun & 11 & $14.7 \%$ \\
Total & 75 & $100 \%$ \\
\hline
\end{tabular}

Dari tabel di atas menunjukkan bahwa karakteristik umur remaja Pondok Pesantren Sabilurrosyad Gasek Malang dengan responden terbanyak berusia 15-18 tahun yaitu 24 siswi $(46,7 \%)$ dan responden paling sedikit berusia 23-25 tahun yaitu 11 mahasiswi $(14,7 \%)$. 


\subsubsection{Karakteristik Responden Menurut Kelas/Semester}

Dari hasil penelitian didapatkan data kategori kelas/semester responden menunjukkan bahwa:

Tabel 2. Distribusi Frekuensi Karakteristik Kelas/Semester Responden

\begin{tabular}{ccc}
\hline Kelas/Semester Responden & Frekuensi & Persentase \\
\hline 3 SMP & 7 & $9.3 \%$ \\
1-3 SMA & 28 & $37.3 \%$ \\
1-8 Kuliah & 40 & $53.3 \%$ \\
Total & 75 & $100 \%$ \\
\hline
\end{tabular}

Berdasarkan tabel di atas menunjukkan bahwa karakteristik kelas/semester pada remaja di Pondok Pesantren Sabilurrosyad Gasek Malang dengan jumlah responden terbanyak pada anak kuliah semester 1-8 yaitu 40 mahasisiwi (53,3\%). Sedangkan jumlah responden paling sedikit pada anak kelas 3 SMP sebesar 7 siswi (9,3\%).

\subsubsection{Siklus Menstruasi}

Variabel siklus menstruasi dinilai dengan dua kategori yaitu teratur dan tidak teratur mendapatkan hasil sebagai berikut:

Tabel 1. Distribusi Frekuensi Siklus Menstruasi

\begin{tabular}{ccc}
\hline \multicolumn{1}{c}{ Siklus Menstruasi } & Frekuensi & Persentase \\
\hline 21-35 hari (Teratur) & 61 & $81.3 \%$ \\
$<21$ hari atau $>35$ hari (Tidak Teratur) & 14 & $18.7 \%$ \\
Total & 75 & $100 \%$ \\
\hline
\end{tabular}

Pada tabel 3 didapatkan hasil dari 75 responden sebanyak 14 siswi/mahasiswi $(18,7 \%)$ tergolong dalam kategori tidak mengalami siklus menstruasi teratur $(>21$ hari atau $<35$ hari), terdapat 61 siswi/mahasiswi $(81,3 \%)$ tergolong dalam kategori mengalami siklus menstruasi teratur (21-35 hari).

\subsubsection{Kualitas Tidur}

Data kualitas tidur didapat dari pengisian kuesioner yang sebelumnya telah dimodifikan oleh peneliti terdahulu. Hasil pengklasifikasian kualitas tidur dibagi menjadi dua kategori yaitu baik, dan buruk dapat dilihat pada tabel di bawah ini:

\section{Tabel 2. Distribusi Frekuensi Kualitas Tidur}

\begin{tabular}{ccc}
\hline Kualitas Tidur & Frekuensi & Persentase \\
\hline Baik (jika kualita tidur $\leq 5$ ) & 23 & $30.7 \%$ \\
Buruk (jika kualitas tidur $>5$ ) & 52 & $69.3 \%$ \\
Total & 75 & $100 \%$ \\
\hline
\end{tabular}


Tabel tersebut menunjukkan bahwa responden mengalami kualitas tidur baik yakni sebanyak 23 siswi/mahasiswi (30,7\%). Sedangkan responden yang mengalami kualitas tidur buruk yakni sebanyak 52 siswi/mahasiswi (69,3\%).

\subsubsection{Status Gizi}

Hasil kuesioner variabel status gizi yang didapat dari 75 responden mendapatkan hasil sebagai berikut:

Tabel 3. Distribusi Frekuensi Status Gizi

\begin{tabular}{lcc}
\hline \multicolumn{1}{c}{ Status Gizi } & Frekuensi & Persentase \\
\hline$<17$ (Sangat Kurus) & 3 & $4.0 \%$ \\
$17,0-18,4$ (Kurus) & 8 & $10.7 \%$ \\
$18,5-25,0$ (Normal) & 49 & $65.3 \%$ \\
$25,1-27,0$ (Gemuk) & 9 & $12.0 \%$ \\
$>27$ (Obesitas) & 6 & $8.0 \%$ \\
Total & 75 & $100 \%$ \\
\hline
\end{tabular}

Berdasarkan tabel 5 diketahui bahwa dari 75 responden sebesar 3 siswi/mahasiswi $(4,0 \%)$ tergolong status gizi sangat kurus. Terdapat sebesar 10,7\% (8 siswi/mahasiswi) tergolong status gizi kurus. Sebesar 65,3\% (49 siswi/mahasiswi) tergolong status gizi normal. Ada 9 siswi/mahasiswi $(12,0 \%)$ tergolong status gizi gemuk. Sedangkan, responden yang mengalami status gizi obesitas yakni sebesar 6 siswi/mahasiswi $(8,0)$.

\subsubsection{Dismenore Primer}

Variabel dismenore primer dinilai dari dua kategori yaitu ya dan tidak mendapatkan hasil sebagai berikut:

Tabel 4. Distribusi Frekuensi Dismenore Primer

\begin{tabular}{lcc}
\hline Dismenore Primer & Frekuensi & Persentase \\
\hline Ya & 66 & $88.0 \%$ \\
Tidak & 9 & $12.0 \%$ \\
Total & 75 & $100 \%$ \\
\hline
\end{tabular}

Dari tabel diatas menunjukkan bahwa sebesar 88,0\% dengan jumlah responden sebanyak 66 siswi/mahasiswi mengalami dismenore primer. Sedangkan sebesar 12,0\% dengan jumlah responden sebanyak 9 siswi/mahasiswi tidak mengalami dismenore primer.

\subsubsection{Analisis Hubungan Siklus Menstruasi Terhadap Dismenore Primer}

Hasil korelasi dengan uji spearman'x rho antara siklus menstruasi terhadap dismenore primer dapat digambarkan seperti dibawah ini, yaitu: 
Tabel 5. Tabulasi Silang Siklus Menstruasi Terhadap Dismenore Primer

\begin{tabular}{lccccc}
\hline \multirow{2}{*}{ Siklus Menstruasi } & \multicolumn{2}{c}{ Dismenore Primer } & Total & P-Value & Koefisien Korelasi \\
\cline { 2 - 3 } & Tidak & Ya & & & \\
\hline 21-35 hari (Teratur) & 1 & 60 & 61 & 0,000 & 0,771 \\
& $1,6 \%$ & $98,4 \%$ & $100,0 \%$ & & \\
$<21$ hari atau $>35$ & 8 & 6 & 14 & & \\
hari (Tidak Teratur) & $57,1 \%$ & $42,9 \%$ & $100,0 \%$ & & \\
Total & 9 & 66 & 75 & & \\
& $12,0 \%$ & $88,0 \%$ & $100,0 \%$ & & \\
\hline
\end{tabular}

Tabel diatas menunjukkan bahwa antara siklus menstruasi dengan dismenore primer memperoleh nilai sebesar 0,000 ( $p$-value $<0,05)$, berarti terdapat hubungan yang signifikan antara siklus menstruasi dengan dismenore primer pada remaja putri.

\subsubsection{Analisis Hubungan Kualitas Tidur Terhadap Dismenore Primer}

Dalam tabel antara kualitas tidur dengan dismenore primer yang dikorelasikan dengan software SPSS 25 mendapatkan hasil bahwa:

Tabel 6. Tabulasi Silang Kualitas Tidur Terhadap Dismenore Primer

\begin{tabular}{lccccc}
\hline \multirow{2}{*}{ Kualitas Tidur } & \multicolumn{2}{c}{ Dismenore Primer } & Total & P-Value & Koefisien Korelasi \\
\cline { 2 - 3 } & Tidak & Ya & & & \\
\cline { 1 - 3 } Baik $(\leq 5)$ & 1 & 22 & 23 & 0,034 & 0,246 \\
Buruk $(>5)$ & $4,3 \%$ & $95,7 \%$ & $100,0 \%$ & & \\
Total & 8 & 44 & 52 & & \\
& $15,4 \%$ & $84,6 \%$ & $100,0 \%$ & & \\
& 9 & 66 & 75 & & \\
\hline
\end{tabular}

Berdasarkan tabel diatas diketahui bahwa hasil korelasi menggunakan uji spearman'x rho mendapatkan nilai sebesar 0,034 (p-value $<0,05$ ). Dari hasil analisis yaitu terdapat hubungan yang signifikan antara kualitas tidur terhadap dismenore primer pada remaja putri.

\subsubsection{Analisis Hubungan Status Gizi Terhadap Dismenore Primer}

Status gizi terhadap dismenore primer dilakukan di Pondok Pesantren Sabilurrosyad Gasek Malang dapat digambarkan pada table 9. Tabel 9 merupakan hasil korelasi spearman'x rho yang dilakukan antara variabel status gizi dan variabel dismenore primer menunjukkan nilai koefisen sebesar 0,364 ( $p$-value $>0,05$ ), yang berarti tidak terdapat hubungan yang signifikan antara status gizi dengan dismenore primer pada remaja putri. 
Tabel 7. Tabulasi Silang Antara Status Gizi Terhadap Dismenore Primer

\begin{tabular}{cccccc}
\hline \multirow{2}{*}{ Status Gizi } & \multicolumn{2}{c}{ Dismenore Primer } & Total & P-Value & Koefisien Korelasi \\
\cline { 2 - 3 } & Tidak & Ya & & & 0,106 \\
\hline$<17$ (Sangat Kurus) & 1 & 2 & 3 & 0,364 & \\
$17,0-18,4$ (Kurus) & $33,3 \%$ & $66,7 \%$ & $100,0 \%$ & & \\
$18,5-25,0$ (Normal) & 1 & 7 & 8 & & \\
& $16,7 \%$ & $83,3 \%$ & $100,0 \%$ & \\
$25,1-27,0$ (Gemuk) & 4 & 45 & 49 & \\
Obesitas (>27) & 2 & $93,2 \%$ & $100,0 \%$ & \\
& $22,2 \%$ & $77,8 \%$ & $100,0 \%$ & \\
Total & 1 & 5 & 6 & \\
& $16,7 \%$ & $83,3 \%$ & $100,0 \%$ & \\
\hline
\end{tabular}

\subsubsection{Uji Omnibus}

Hasil tabel dari uji omnibus dapat digambarkan sebagai berikut:

Tabel 8. Uji Omnibus

\begin{tabular}{lllll}
\hline & & Chi-Square & df & Sig. \\
\hline Step 1 & Step & 25.741 & 3 & .000 \\
& Block & 25.741 & 3 & .000 \\
& Model & 25.741 & 3 & .000 \\
\hline
\end{tabular}

Berdasarkan tabel 10 hasil uji omnibus menunjukkan bahwa penambahan variabel independen dapat memberikan pengaruh secara signifikan dengan variabel dependen. Sehingga hipotesis alternatif dapat diterima dan memperoleh nilai signifikan sebesar 0,000.

\subsubsection{Parameter Estimasi}

Pada tahap terakhir ini dilakukan pendugaan parameter estimasi yang memperoleh hasil sebagai berikut:

Tabel 9. Parameter Estimasi

\begin{tabular}{|c|c|c|c|c|c|c|c|c|c|}
\hline & \multirow[t]{2}{*}{ B } & \multirow[t]{2}{*}{ S.E } & \multirow[t]{2}{*}{ Wald } & \multirow[t]{2}{*}{ df } & \multirow[t]{2}{*}{ Sig. } & \multirow[t]{2}{*}{$\operatorname{Exp}(B)$} & \multicolumn{2}{|c|}{ 95\% C.I for EXP (B) } \\
\hline & & & & & & & & Lower & Upper \\
\hline \multirow[t]{5}{*}{ Step $1^{\mathrm{a}}$} & Siklus & -4.427 & 1.240 & 12.746 & 1 & .000 & .012 & .001 & .136 \\
\hline & Menstruasi (1) & & & & & & & & \\
\hline & $\begin{array}{l}\text { Kualitas Tidur } \\
\text { (1) }\end{array}$ & .177 & 1.494 & .014 & 1 & .906 & 1.194 & .064 & 22.331 \\
\hline & Status Gizi (1) & -.085 & .615 & .019 & 1 & .890 & .918 & .275 & 3.066 \\
\hline & Constant & 8.498 & 3.246 & 6.854 & 1 & .009 & 4906.457 & & \\
\hline
\end{tabular}

Dari tabel tersebut dapat dilihat bahwa variabel siklus menstruasi mendapatkan hasil sebesar $p=0,000(<0,05)$ dan nilai $\operatorname{EXP}(B)$ yakni 0,012 , maka dari hasil diatas mendapatkan 
kesimpulan bahwa kejadian dismenore primer pada remaja putri dengan variabel siklus menstruasi baik memiliki pengaruh yang tidak terlalu besar.

\subsection{Pembahasan}

\subsubsection{Hubungan Siklus Menstruasi Terhadap Dismenore Primer}

Berdasarkan hasil penelitian di Pondok Pesantren Sabilurrosyad Gasek Malang pada remaja putri, didapatkan hasil dari keseluruhan responden (75 responden) sebanyak 61 responden $(81,3 \%)$ mengalami siklus menstruasi teratur, sedangkan sebanyak 14 responden $(18,7 \%)$ tidak mengalami siklus menstruasi teratur.

Terdapat hasil penelitian yang serupa di berbagai negara diantaranya penelitian Felicia, et. al (2015) mengenai siklus menstruasi di Turki, dimana ketidakteraturan pola menstruasi dialami oleh remaja wanita sebanyak $31,2 \%$. Selain itu, remaja wanita di India mengalami ketidakteraturan pola menstruasi sekitar 22,1\% (Larasati \& Alatas, 2016). Terdapat beberapa faktor yang dapat menyebabkan siklus menstruasi terganggu yaitu jarang melakukan aktivitas fisik, asupan status gizi yang dikonsumsi kurang baik, dan mengalami stress.

Penelitian ini mendapatkan hasil uji korelasi spearman'x rho sebesar 0,000, sehingga memperoleh kesimpulan yaitu terdapat hubungan signifikan antara siklus menstruasi terhadap dismenore primer pada remaja putri di Pondok Pesantren Sabilurrosyad Gasek Malang. Setara penelitian Juliana, et. al (2019) dilakukan di SMA N 1 Manado memperoleh hasil korelasi uji Chi-Square yakni 0,023, menyebutkan bahwa variabel dismenore primer dan gangguan siklus menstruasi memiliki hubungan yang bermakna. Dalam tabulasi silang tabel 7 dimana 60 responden mengalami siklus menstruasi teratur dan dismenore primer, akan tetapi sebanyak 6 responden tidak mengalami siklus menstruasi teratur tetapi mengalami dismenore primer. Hal ini disebabkan karena remaja wanita mengalami siklus menstruasi dengan berbagai macam variasi, dimana siklus menstruasi berkisar antara 21-35 dialami sebesar $90 \%$ remaja wanita, untuk siklus menstruasi sekitar 28 hari dialami hanya 10\% saja. Selain itu, berdasarkan hasil tabulasi silang tabel 7 dimana remaja wanita di Pondok Pesantren Sabilurrosyad Gasek Malang mengalami siklus menstruasi teratur yakni 98,4\% (60 responden), serta berdasarkan hasil distribusi frekuensi mengalami siklus menstruasi teratur yakni 81,3\% (61 responden) walaupun responden tersebut mengalami dismenore primer.

Dismenore primer dapat muncul karena terjadinya siklus menstruasi tidak teratur setiap bulannya, dimana kemungkinan tingkat nyeri yang dirasakan pada siklus menstruasi tidak teratur makin besar (Juliana, et. al., 2019). Hal ini disebabkan karena adanya ketidakseimbangan hormon prostaglandin F2-alpha di awal menstruasi sehingga menimbulkan kontraksi yang begitu kuat dan sering terjadi pada otot uterus (Janiwarty \& Pieter, 2013). Akan tetapi, penjelasan tersebut bertolak belakang dengan hasil uji statistik korelasi yang telah didapat dan datanya diolah menggunakan SPSS versi 25 oleh peneliti pada saat penelitian di Pondok Pesantren Sabilurrosyad Gasek Malang.

Remaja wanita yang mengalami gangguan siklus menstruasi dapat menyebabkan terjadinya masalah kesuburan (Saryono \& Sejati, 2009). Gangguan tersebut seperti polimenorea ( $<21$ hari), oligomenorea ( $>35$ hari), dan amenorea ( $>3$ bulan). 


\subsubsection{Hubungan Kualitas Tidur Terhadap Dismenore Primer}

Berdasarkan hasil keseluruhan responden dari 75 responden, didapatkan hasil uji statistik yang mengalami kualitas tidur baik sebesar 23 responden (30,7\%), sedangkan sebanyak 52 responden $(69,3 \%)$ memiliki kualitas tidur buruk.

Dalam penelitian ini didapatkan hasil uji korelasi menggunakan uji Spearman'x rho sebesar $0,034(p<0,05)$ hal ini memiliki hubungan signifikan terhadap kualitas tidur dengan dismenore primer terhadap remaja putri di Pondok Pesantren Sabilurrosyad Gasek Malang. Sejalan penelitian Yudhanti, et. al (2014) Mahasiswi FK Universitas Sebelas Maret, didapatkan nilai signifikan sebesar $0,001(p<0,05)$ dimana nilai tersebut mempunyai hubungan erat antara dua variabel yaitu kualitas tidur dan dismenore primer. Sesuai tabel distribusi frekuensi sebesar 69,3\% (52 responden) memiliki kualitas tidur buruk. Jadwal kegiatan yang cukup padat merupakan faktor penyebab terjadinya kualitas tidur buruk dialami oleh remaja putri di Pondok Pesantren. Selaras penelitian Brick, et. al (2010) menyatakan bahwa sebagian mahasiswa kedokteran mengalami kualitas tidur buruk dikarenakan akibat dari tuntutan akademik yang dialami selama menjalankan pendidikannya.

Didapatkan hasil korelasi mengenai gambaran kualitas tidur terhadap mahasiswi FK, sebesar 51\% (51 dari 100 mahasiswi) mengalami kualitas tidur buruk (Fauzan, 2018). Hasil penelitian (Lima, 2009) dilaporkan sebanyak 60\% mahasiswa tingkat akhir mengalami kualitas tidur lebih tinggi, dibanding dengan mahasiswa tingkat pertama $(42,3 \%)$ dan tingkat kedua $(11,5 \%)$ di salah satu Universitas Kedokteran Brazil.

Hal ini disebabkan karena pengurangan tidur hingga 4 jam dapat meningkatkan prostaglandin sebagai mediator nyeri dan bioavailabilitas agen-agen inflamasi seperti Interleukin-6 (IL-6) dan Tumor Necrosis Factor Alpha (TNF $\alpha$ ) yang merupakan pencetus nyeri yang paten dan termasuk pencetus nyeri saat menstruasi (Haack, et. al., (2007) dalam Jurnal Delistianti, et. al., (2019). Selain itu, penurunan serotonin di dalam tubuh dapat diakibatkan oleh kualitas tidur buruk yang diderita oleh remaja wanita. Berkurangnya serotonin tersebut, berdampak pada meningkatnya kecemasan, depresi, serta meningkatnya sensitivitas terhadap nyeri (Mcllwain (2006) dalam Jurnal Yudhanti, et. al (2014). Sejalan dengan penelitian Wiliam (2013) bahwa remaja sangat memerlukan waktu tidur yang cukup berkisar selama 7-9 jam setiap harinya. Waktu tidur tersebut diperlukan oleh remaja umur 18-25 tahun. Hal ini karena pada remaja yang memiliki waktu tidur kurang dapat mempengaruhi daya ingat atau memori remaja tersebut. Selain itu, berdasarkan penelitian Woosley \& Lichstein (2014) remaja wanita yang sering insomnia akan mengalami dismenore lebih berat dibandingkan remaja wanita yang tidak insomnia.

\subsubsection{Hubungan Status Gizi Terhadap Dismenore Primer}

Berdasarkan hasil korelasi dari 75 responden, didapatkan sebanyak 65,3\% (49 siswi/mahasiswi) masuk dalam kategori status gizi normal serta paling banyak dialami oleh remaja wanita, untuk kategori status gizi gemuk sebesar 12,0\% dengan jumlah responden yakni 9 siswi/mahasiswi. Untuk kategori status gizi kurus didapatkan hasil uji statistik sebesar $10,7 \%$ dengan jumlah responden yakni 8 siswi/mahasiswi, dan untuk jumlah responden pada kategori status gizi obesitas yakni 6 responden $(8,0 \%)$. Sedangkan hasil uji statistik untuk jumlah responden paling sedikit terdapat pada kategori status gizi sangat kurus yakni 3 responden $(4,0 \%)$. 
Diperoleh nilai korelasi spearman'x rho sebesar $0346(p>0,05)$. Berdasarkan analisis data maka variabel status gizi dengan dismenore primer tidak memiliki pengaruh satu sama lain. Hal ini disebabkan karena 65,3\% (49 responden) mengalami kategori status gizi normal dan tidak mengalami dismenore primer.

Berbanding terbalik dengan hasil penelitian sebelumnya, pada siswi SMK Negeri 10 Medan yang dilakukan oleh Sophia, et. al (2013) yang mendapatkan hasil menggunakan uji korelasi chi-square sebesar 0,043 yang berarti antara status gizi dengan dismenore primer memiliki hubungan yang bermakna. Sebesar 0,008 $(<0,05)$ merupakan hasil analisis menggunakan uji chi-square (Beddu, et. al., 2015). Berdasarkan hasil penelitian Cholifah \& Hadikasari (2015) remaja putri D3 Kebidanan Fakultas Ilmu Kesehatan Universitas Muhammadiyah Sidoarjo, didapatkan hasil analisis uji statistik menggunakan uji Exact Fisher sebesar 0,023 $(p<0,05)$ dimana status gizi dan dismenore primer memiliki hubungan.

Dalam buku Daftary \& Patky (2009), penyebab dismenore primer ditemukan pada status gizi overweight (gemuk), obesitas dan underweight (sangat kurus). Oleh sebab itu, terlalu banyak jaringan lemak pada remaja wanita, dimana status gizi gemuk akan memicu terjadinya hiperplasia pembuluh darah di organ reproduksi wanita sehingga menimbulkan dismenore primer (Sibagariang, et. al., 2010). Jika fungsi reproduksi terganggu, hal tersebut akan menimbulkan terjadinya dismenore. Akan tetapi, dampak tersebut bisa membaik dengan cara memberi asupan nutrisi yang baik untuk dikonsumsi oleh tubuh (Tristiana, 2017).

\subsubsection{Hubungan antara Siklus Menstruasi, Kualitas Tidur, dan Statuz Gizi Terhadap Dismenore Primer}

Dari uji regresi logistik dalam analisis multivariat mendapatkan hasil yaitu tidak ada variabel bebas yang bekerja bersama-sama dalam kejadian dismenore primer. Kejadian dismenore primer dapat terjadi karena adanya pengaruh dari variabel siklus menstruasi dibanding variabel lainnya berdasarkan hasil analisis. Sesuai dengan pernyataan (Janiwarty \& Pieter, 2013) menyebutkan bahwa otot uterus berkontraksi kuat dan sering terjadi di awal menstruasi karena adanya ketidakseimbangan hormon prostaglandin F2-alpha menyebabkan terjadinya dismenore primer. Namun sejauh ini belum terdapat penelitian yang menganalisis hubungan siklus menstruasi, kualitas tidur, dan status gizi dengan dismenore primer pada remaja putri sampai analisis multivariat.

\section{Simpulan}

Kesimpulan yang didapat dalam penelitian di atas yaitu: terdapat hubungan yang signifikan antara siklus menstruasi terhadap dismenore primer pada remaja putri di Pondok Pesantren Sabilurrosyad Gasek Malang $(p=0,000)(\alpha<0,05)$ dengan kekuatan korelasi kuat $(0,771)$, terdapat hubungan yang signifikan antara kualitas tidur dengan dismenore primer pada remaja putri di Pondok Pesantren Sabilurrosyad Gasek Malang $(p=0,034)(\alpha<0,05)$ dengan kekuatan korelasi lemah $(0,246)$, Tidak ada hubungan yang signifikan antara status gizi terhadap dismenore primer pada remaja putri di Pondok Pesantren Sabilurrosyad Gasek Malang $(p=0,364)(\alpha>0,05)$ dengan kekuatan korelasi sangat lemah $(0,106)$, dan Tidak ada pengaruh secara signifikan antara kualitas tidur $(p=0,906)(\alpha>0,05)$ dan status gizi $(p=0,890)$ $(\alpha=0,05)$ terhadap dismenore primer. Sedangkan terdapat pengaruh secara signifikan antara siklus menstruasi $(p=0,000)(\alpha<0,05)$ terhadap dismenore primer dengan nilai $\operatorname{EXP}(B)$ yakni 0,012 . 


\section{Daftar Rujukan}

Adriani, M., \& Wirjatmadi, B. (2012). Peranan Gizi dalam Siklus Kehidupan. Jakarta: Kencana Prenada Media Group.

Almatsier, S. (2010). Prinsip Dasar Ilmu Gizi. Jakarta: Gramedia Pustaka Utama.

Bataha, Yolanda, B., Rondonuwu, R., \& Moniung, Sarah, Y. (2014). Hubungan tekanan darah sistolik dengan kualitas tidur pasien hipertensi di Puskesmas Bahu Manado. Jurnal Keperawatan, 2(2), 1-8.

Beddu, S., Mukarramah, S., \& Lestahulu, V. (2015). Hubungan Status Gizi dan Usia Menarche Dengan Dismenore Primer Pada Remaja Putri. The Southeast Asian Journal of Midwifery, 1(1), 16-21.

Brick, C.A., Seely, D.L., \& Palermo, T. . (2010). Association Between Sleep Hygiene And Sleep Quality in Medical Students. Behavioral Sleep Medicine, 8(2), 113-213.

Cholifah \& Hadikasari, A. . (2015). Hubungan Anemia, Status Gizi, Olahraga, Dan Pengetahuan Dengan Kejadian Dismenore Primer Pada Remaja Putri. Jurnal Kebidanan (Midwiferia), 1(31-43).

Daftary, S, N., \& Patky, A. (2009). Reproductive Endocrinology \& Infertility. New Delhi: BI Publication Pvt Ltd.

Dawood. (2010). Primary Dysmenorrhea Advances in Pathogenesis and Management. Journal Obtetric and Gynaecology, 108 (2), 122-133.

Delistianti, R, Y., Irasanti, S, N., M, Ferri, A., Ibnusantosa, R, G., \& Sukarya, W, S. (2019). Hubungan Kualitas Tidur Dengan Kejadian Dismenore Primer Pada Mahasiswi Fakultas Kedokteran Universitas Islam Bandung. Jurnal Integrasi Kesehatan \& Sains, 1(2), 134-138.

Fauzan, R. (2018). Gambaran Kualitas Tidur Pada Mahasiswa Fakultas Kedokteran Universitas Sumatera Utara Tahun Akademik 2013/2014 [Skripsi]. Medan: Sumatera Utara.

Felicia., Hutagol, Esther., \& Kundre, R. (2015). Hubungan Status Gizi Dengan Siklus Menstruasi Pada Remaja Putri Di PSIK FK Unsrat Mandao. Jurnal Keperawatan, 3(1), 1-7. Retrieved from https://ejournal.unsrat.ac.id/

Hendarto, H. (2011). Gangguan Haidatau Pendarahan Uterus Abnormal. Jakarta: Yayasan Bina Pustaka.

Isnaeni, D. N. (2010). Hubungan Antara Stres Dengan Pola Menstruasi Pada Mahasiswa D IV Kebidanan Jalur Reguler Unibersitas Sebelas Maret Surakarta. 1-54. Retrieved from https://digilib.uns.ac.id/dokumen/download/16524/MzE2OTQ=/Hubungan-antara-stres-denganpola-menstruasi-pada-mahasiswa-d-IV-kebidanan-jalur-reguler-UniversitasS-Maret-Surakartaabstrak.pdf.

Janiwarty, B \& Pieter, H. Z. (2013). Pendidikan Psikologi untuk Bidan Suatu Teori dan Terapannya. Yogyakarta: Rapha Publishing.

Juliana, I., Rompas, S., \& Onibala, F. (2019). Hubungan Dismenore Dengan Gangguan Siklus Haid Pada Remaja Di SMA N 1 Manado. Jurnal Keperawatan, 7(1), 1-8.

Khasanah. K. (2012). Kualitas Tidur Lansia Balai Rehabilitasi Sosial "MANDIRI" Semarang. Jurnal Nursing Studies, 1(1), 189-196.

Larasati, TA., \& Alatas, F. (2016). Dismenore Primer dan Faktor Risiko Dismenore Primer pada Remaja. 5(3), 7984. Retrieved from https://juke.kedokteran.unila.ac.id/

Lima, P. . (2009). Change in Sleep Habits of Medical Students Accroding to Class Starting Time: a Longitudinal Study. Sleep Sciences, 2(2), 92-95.

Saguni, F.C., Madianung, A., \& Masi, G. (2013). Hubungan Dismenore Dengan Aktivitas Belajar Remaja Putri di SMA Kristen 1 Tomohon. Jurnal Keperawatan, 1(1), 1-6.

Saryono \& Sejati. (2009). Sindrom Premenstruasi Mengungkap Tabir Sensitifitas Perasaan Menjelang Menstruasi. Yogyakarta: Nuha Medika.

Sibagariang, E., Pusmaika, R., \& R. (2010). Kesehatan reproduksi wanita. Jakarta: Trans Info Media.

Sinaga et al. (2017). Manajemen Kesehatan Menstruasi. Jakarta: IWWASH.

Sophia, F., Muda, S., \& J. (2013). Faktor-Faktor Yang Berhubungan Dengan Dismenore Pada Siswi SMK Negeri 10 Medan Tahun 2013. $\quad$ Retrieved rom https://jurnal.usu.ac.id/index.php/gkre/article/download/19292/9063

Tristiana, A. (2017). Hubungan Aktivitas Fisik Dengan Kejadian Dismenore Primer Pada Pondok Pesantren X Di Kabupaten

Bogor.

1-51.

Retrieved

from 
Waryana. (2010). Gizi Reproduksi. Yogyakarta: Pustaka Rihama.

Wiliam, M, C. (2013). Hubungan Kualitas Tidur Dengan Konsentrasi Pada Mahasiswa Angkatan 2009 Fakultas Kedokteran Universitas Sumatera Utara. Undergraduate Thesis. Retrieved from http://repository.usu.ac.id/handle/123456789/35223.

Woosley, JA., \& Lichstein, K. (2014). Dysmenorrhea The Menstrual Cycle And Sleep. Behavioral Medicine., 40(1), $14-21$.

Yudhanti, Melinda, S., Balgis., \& W. (2014). Kualitas Tidur Yang Buruk Meningkatkan Kejadian Dismenore Pada Mahasiswi Fakultas Kedokteran Universitas Sebelas Maret. Nexus Kedokteran Komunitas, 3(2), 219230.

Yusuf, S. (2012). Psikologi Perkembangan Anak dan Remaja. Bandung: Remaja Rosdakarya. 